\title{
THE EVOLVING CONCEPT OF LEX MONETAE IN INTERNATIONAL AND EUROPEAN MONETARY LAW ${ }^{* *}$
}

\begin{abstract}
The subject of analysis in the paper is the examination of the application and derogation of the contemporary international and European monetary law principles. In this context, the first part of the paper points to the specificity of the subject of legal regulation of international monetary relations and examines the normative features of the international monetary system. The second part of the paper points to the basic postulates of international monetary law, embodied in the principles of traditional lex monetae and lex contractus, with particular emphasis on the application of these principles in globalized financial flows. The subject of the analysis is to identify the new wave in development of the legal regulation of monetary relations, as well as the role of International Monetary Fund in the process of money regulation, which, according to the author, has significant implications not only for preserving the acquis and values of the international monetary order, but also for the maintenance of internal monetary stability.
\end{abstract}

Keywords: monetary law, EU, monetary jurisdiction, International Monetary Fund, lex monetae.

\section{Introduction}

The basic reason for studying the discipline of European and International monetary law is reflected in the need for legal regulation of international monetary relations that alter the scope of monetary sovereignty components. It is interesting that, historically, the concept of monetary sovereignty has not enjoyed the recognition by the international community for a long time, although it is a key institute of international monetary law that has not explicitly found its justification and protection in Articles of Agreement of the International Monetary Fund (IMF). In fact, the first official recognition of this concept does not have its source in jurisprudence, but in the case law of the former Permanent Court of International Justice, in a judgment concerning the legitimacy of a

\footnotetext{
* PhD, Assistant Professor, Faculty of Law, University of Niš, Serbia, e-mail: markod1985@prafak.ni.ac.rs.

** This paper is a result of research conducted within the project „Harmonisation of Serbian Law with EU Law (2013-2020)", carried out by Faculty of Law, University of Niš.
} 
public loan in the case of France vs. Serbia (where the state prerogative to independently and completely regulate all issues related to the definition and use of the its currency is explicitly recognized). ${ }^{1}$ In the globalised economic and financial relations there is a qualitative evolution of the monetary sovereignty concept in the meaning of its adapting to modern economic occasions and international circumstances.

It is clear that due to the conceptual disagreement of the national and international monetary policy programmes, the legislator often made trade-offs, but the restriction of national measure in the determination of monetary targets is fulfilled by the legal power of the international monetary instrument (agreement), characterised by a wider field of application, plenty of financial and monetary support measures, as well as prudent monetary cooperation (Dimitrijević, 2018, pp. 49-52). At the same time, we need to be aware that monetary policy is not just an ordinary set of administrative activities that must be under judicial control in order to exercise and protect individual rights. It implies the use of complex techniques and models aimed at sustainable economic growth which judges usually don't understand. While it is clearly understood for monetary law scholars that monetary regimes must be effective, the fact is that the concept of efficiency today still remains a little bit abstract, as it is primarily determined by the mechanics of designing legal solutions, which include a careful selection of doctrinal and legal concepts, form, language, style, and "luck" in regaining the right of certain views (Mousmoti, 2019, p. 7). In the field of monetary law, as a hybrid branch of law with private and public interest represented, the requirement of normative efficiency is further complicated, because at the same time, monetary legal norms, due to their dialectical connection to the economic law, must satisfy the condition of economic efficiency, too. This connection is a natural product of legal definition of money, which in attempts to be optimal must include some economic functions of money as commodity and monetary sovereignty prerogative (Gleson, 2018, p. 27).

\section{The international monetary system in contemporary law}

In the monetary law literature, it is stated that it is not possible with great precision to determine the exact date of the constitution of the international monetary system (Byttebier, 2017, pp. 1-10). Of course, we must point out that the manifestation forms, structure and techniques of contracting international monetary treaties have been changed significantly since the expiration of the classic gold standard. The dynamics in the regulation of specific legal and economic relations is accompanied by a change in the awareness of legal entities, which is why the process of finding a compromise solution can be quite complicated and jeopardised by the implacable legal argumentation of monetary entities that appear in all "issues of state money" as a matter of particular importance to life and the survival of one nation. Namely, the interests of states in establishing legal regulations on international monetary relations cannot be unilaterally reduced to economic

${ }^{1}$ Case Concerning the Payment of Various Serbian Loans Issued in France (France v. Serbia), Judgment of 12 July 1929, PJC Rep Series A Nos 20-21. The main question referred under what conditions the holders of Serbian bonds were entitled to obtain the payment of nominal amount of their coupons. 
or political ones, as there are many other (non-economic) factors, such as geographical, cultural, ideological, and even affective one (which condition their appearance in practice). At this place a question must be raised: Can common practice created by the international monetary order have primacy over legal rules in the regulation of international monetary relations? Of course, it is obvious that, in the absence of a legal rule that would apply to a specific national problem (issue) from an international monetary relationship, common practice as a subsidiary principle will be applied, although in the majority of cases the absence of a particular legal rule means the absence of a principle (Gold, 1979, p. 36).

The concept of an international monetary system itself is now defined primarily in the legal sense. For the first time, the term is used within the General Arrangements to Borrow, which are an integral part of the IMF Founding Agreement. As such, the term is used in legal traffic from January 5, 1962 (more precisely, it became effective after the postponement clause was executed on October 24), when a loan agreement between the IMF and ten borrowers was concluded. The term itself has gained far greater legal significance when it was incorporated into the Second Amendment of the Agreement on the IMF (although as such it is not mentioned anywhere in the basic text of the Agreement). In the usual sense, under this term, we include the relations between the member states that are members of the IMF that oversees the management of the entire international monetary system. Nevertheless, we should be cautious about reducing the term per se to its purely normative elements, because such approach does not leave enough room for the application of a principle that would unite all the elements (therefore, those no-normative) of international relations in a universal way. The problem with the identification of the international monetary system with its normative elements is also reflected in the fact that these elements are variable, i.e. that their content and meaning can be interpreted differently over time. At the same time, some new elements may need to be taken into consideration or need to be removed from the definition framework. Thus, for example, in 1969, the concept of holding reserves in the form of special drawing rights was introduced with the adoption of the First Amendment to the IMF Agreement, or the elimination of gold from primary reserves was established by the Second with the amendment of the Agreement.

The definition of the international monetary system can be given from the aspect of the goal and the essence of the currency problems that it wants to solve. The problem with this approach is that it does not provide the establishment of criteria that separate countries that are not IMF members, but also participate in the international monetary system. The best theoretical principle in defining international monetary system is the one based on the overall payments balance of the states participating in international monetary relations (which are regulated by national monetary legislation). The main monetary authorities in the creation of these rules are the central bank, funds for economic development and stabilisation of economic flows, public debt agency and similar fiscal agencies. Also, we can define international monetary system as a set of rules governing the balance of payments seen as the totality of economic transactions of one country with the rest of the world.

In understanding the precise concept of international monetary system, the theory of monetary law governed the differences between the two doctrines. According to the first one, this term implies all the rules that apply to transactions between monetary authorities 
and private individuals if those payments affect the total balance of payments in any aspect. According to the second doctrine, it is considered that the term can only be applied to those rules that regulate transactions between monetary authorities in the form of international contracts. The problem is that according to some theoretical considerations, contracts concluded between central banks cannot be treated as classic international treaties (which is partially our opinion, too). The fact that this category of contract cannot be placed in any of the existing classifications in international public law per se remains without effect in the matter of international monetary law, because such contracts are natural and logical manifestations of the legal and business capacity of supreme monetary institutions in international transactions.

Of course, the impact of the international public law on the international monetary law is undeniable and can be seen in the development of the IMF from its foundation, through the extension of its competence to proposals for institutional reforms and the introduction of new arrangements. Certainly, this impact is strictly determined and limited by the founding members, because the IMF has its own corpus juris since it is the main promoter of the development and regulation of the international system.

The fact is that the international monetary system cannot be considered as a simple set or sum of national monetary systems (their national monetary regulations and participant states in international monetary relations), because it is a legal institute characterised by supranational rules, supranational entities with global legal and economic consequences. Consequently, we consider that there is a relationship of complementarity between the international and national monetary system, because a well-regulated and established national system implies a functioning supranational system. This means that the legislator must make greater efforts in order to create and search for optimal monetary rules whose effects will spill over to the international monetary environment, and when this is not possible, the international environment must impose its own rules to "weak" national monetary authorities and thus strike a balance. The conclusion is that the logic of both systems is the same, but paths of its manifestation are different and independent, which is very useful in practice, because the weaknesses of the small national monetary system can be replaced by the authoritative and credible functioning of the international monetary system.

\section{The principles of international and European monetary law}

The principles of international monetary law are determined by the rules of national monetary law that have extraterritorial dimension, but also in the new circumstances in cases (especially evident in terms of global economic and financial crises) when the states conclude special international agreements with the new monetary institutions or when they decide to join monetary unions and international monetary and financial organisations. We are of the opinion, that in international monetary law we can distinguish borrowed principles (from the sphere of national monetary law and international economic and financial law) and the original principles that its subjects develop independently. The 
theoretical understanding of these principles as primary (in the context of borrowed) and secondary (in the context of the original ones) have relative importance in jurisprudence, since both groups of principles must be respected by monetary entities at all levels of monetary governance. It is only through their synchronised action that it is possible to provide a contribution to achieving international monetary stability. Today, the most important principles have found their place and confirmation in the new legal mechanisms of economic policy coordination within the Eurozone and they are regulated by the provisions of the EU's agreement and the Washington Agreement establishing the Bretton Wood's system. Of course, these principles cannot be viewed isolated from the principles of national monetary law defined by national monetary acts (central bank laws, monetary strategies and, in particular, public debt management strategies).

\subsection{Lex monetae in traditional monetary law}

The basic principle of monetary law is the principle of lex monetae which implies that entities that conclude a public loan contract are generally free to choose the currency in which they will be denominated, but once they make this choice no later decisions of the State issuing can affect its validity. This means that replacing the existing currency with a new one (which could be observed in some countries during the period of hyperinflation to avoid a complete collapse of the monetary system) does not affect the nature and duration of the contractual monetary obligation (Giovanoli, 2000, pp. 122-123). The monetary literature states that this principle implies not only to the definition of a currency unit but also determines its subunits as well as specific items that have the status of a legal tender. Widely viewed, it is clear that the principle of lex monetae is in the function of protecting the legal security and the interests of bona fides contracting parties. The principle finds its place in the Charter of the United Nations (Art. 2 pg. 7) in the form of state nominalism, i.e. state theories on the legal definition of money. This principle can also be defined in a negative way, as an inability of states to influence the determination of monetary units in other countries.

The application of the principle follows the perception of civil law that monetary obligations are indestructible, even in case of termination of the currency in which the contract is concluded. Various theoretical approaches to the content of the principles can be found in the literature of monetary law. It is common to make a distinction between the principles of the lex monetae in the wider and broader sense (Giovanoli, 2000, pp. 153-154). The narrow definition includes the right to define the currency (in particular, the segment of the old currency exchange with a new one), while the wider definition includes all primary and secondary legislation protecting the domestic currency. A narrow definition gave its interpretation to the Taipei Conference of the Association for International Monetary Law, understood as "the right of a state or group of countries that have a common currency to define or redefine a currency unit and to determine the exchange rate between the new and the old currency unit" (that is, the unit they want to substitute) which includes the definition of the so-called recurrent link. 


\subsection{Monetary dimension of lex contractus}

The mentioned principle of lex monetae should not be confused with the principle of legal continuity (lex contractus or lex cause), which implies the freedom of contracting parties to conclude a particular contract (Lastra, 2015, pp. 16-17). The freedom to conclude a contract and to determine all of its essential elements (lat. essentialia negotii) and sporadic elements are the universal principles of civil law. Its contents also include the issue of legal protection of interests of the contracting parties in the event of a change in the particular circumstances under which the contract was concluded, or the issue of its validity, which in the field of monetary obligations has special consequences in case of conversion of the currency in which the contract on a public loan was concluded.

Under the conditions of monetary integration, this principle was especially relevant in the formation of the European economic and monetary union (EMU), through the liberalisation of economic and financial flows, the creation of a European monetary system and the introduction of a single currency (Hermann \& Dornacher, 2017, p. 99). For this reason, EC Regulation 1103/97 confirmed the continuity of previously concluded contracts on monetary flows and transfers in order to protect the interests of the legal order, and in particular the principles of already acquired rights (the principle of retention).

In the case of the EU, the majority of authors state that the unilateral transfer of monetary sovereignty is realised without the contextual transfer of legislative and regulatory powers. This fact is best illustrated by the centralisation of monetary policy at the communitarian level and the financial supervision that is still carried out by the national central banks. The controversy arising from this plan is due to the fact that the lex monetae has been transferred to the level of the EU. These understandings are confirmed by the fact that all Member States retained a certain degree of influence on the monetary policy that is best reflected in the exercise of the voting rights of the governors of the national central bank in the Board of Directors of the ECB. The great challenge in determining the monetary sovereignty in EMU is measuring the level of remaining national monetary sovereignty and setting the boundaries among the members, because it is hard to determine where the sovereignty of one Member State actually ends and where the monetary sovereignty of another Member State begins. The evolution of lex monetae is very evident in the example of European banking union which represents a centralisation of banking policy under the role of European Council. The structure of the Banking Union is based on three pillars: Single Supervisory Mechanism, Single Resolution Mechanism and related financing mechanisms such as Common Deposit Guarantee Fund, the Single Occurrence Deposit Insurance Scheme and the Common Security Mechanism (the so-called credit line). Creating a complete banking union would eliminate all the deficiencies of national supervision of banks, which at the same time implies both the stability of the banking system and the stability of the public finances of the Member States. There are two aspects to this link that are reflected in the requirement to protect relevant state funds from the financial pressures that result from the restructuring of insolvent banks and at the same time protect the banks from the debt monetisation (Binder \& Gorstos, 2017, p. 11). Although the ECB is the supreme monetary institution, its work can be limited by 
the application of the principle of institutional equilibrium, which is closely related to the Meroni doctrine $e^{2}$ on the delegation of authority, which defines the pillars and scope of the institutional balance of power (Lackoff, 2017, p.10).

At this point, we must emphasise the importance of monetary disputes as a special kind of administrative disputes, which involve a central bank (active or passive procedural legitimacy) as the keeper of lex monetae. Due to the specific nature of relationships and outcomes, monetary disputes cannot be guided by the interests of the politically influential members of the EU and justified by reasons of pragmatism. They must be primarily motivated by the protection of supreme monetary institutions that perform their tasks in the interests of society and economy, which was, in our opinion, confirmed in the OMT case (outright monetary transaction). ${ }^{3}$ The European Court of Justice confirmed legitimacy and legalities to the proposed measures of the ECB, explaining it by the fact that the OMT program falls under the program of a unified monetary policy which the ECB conducted in accordance with the monetary strategy in order to preserve monetary stability (i.e. price stability as the primary goal that is more consistently realised by the application of these measures). We can note that in monetary disputes the requirements for the assessment of constitutionality and legality are subject to certain limitations. It is clear from the Court's decision that the conduct of monetary policy requires the possession of expert knowledge and expertise, which in European monetary law only ECB enjoyed with full discretionary powers for their implementation. ${ }^{4}$ Although for some theorists, this decision represents another confirmation of the expansion competence trend of the communitarian institutions by the provisions of secondary legislation, we consider that in this case the conduct of the ECB was not contrary to the provisions of primary law, but rather represents a new way of manifesting the competence in conditions of crisis.

\section{External effects of lex monetae principle}

Although the mentioned principle according to its nature predominantly has a territorial application, in certain situations it can enjoy extraterritorial application (validity). These are the cases of depression, devaluation, currency imbalance and the imposition of foreign exchange controls (Proctor, 2012, pp. 505-509). It is very important to point out this fact because national monetary prerogatives can also be subject of control in international courts, which is otherwise established in Art. 36 of the Statute of the International Court of Justice. For example, although the protection of sovereign monetary powers is indisputable in peacetime circumstances, the question arises as to what happens to the object of protection in war circumstances, and can the provisions of

\footnotetext{
${ }^{2}$ The Meroni doctrine refers to the possibility of EU institutions to delegate powers and tasks to the regulatory bodies and agencies, but without broad discretion. It is defined by the European Court of Justice judgment in cases C-9/56 and C-10/56 (Meroni v High Authority [1957/1958] ECR 133).

${ }^{3}$ This program contains monetary measures for buying bonds in secondary financial markets.

${ }^{4}$ Given that in monetary disputes, the court cannot impose the essence of monetary measures (because it does not have competence for such a thing).
} 
Hague Convention (1907) that prohibit the change of the currency system in the occupied states by the occupiers be applied. It is interesting to note that the change of currency system in post-war Germany by the Alliance forces was justified by the fact that the former state as such had ceased to exist and that there was no place to apply the provisions of the Convention, while during the crisis in Iraq, the UN Security Council called for respect for the same Convention. Based on these examples, it is noted that the introduction of a new currency per se is not a violation of the provisions of the Hague convention in the part concerning the undertaking of economic measures in the field of monetary system, so that the admissibility of the measure will be assessed depending on its eventual confiscatory character and interest in the protection of public goods, because monetary stability de facto represents a public good. Similarly, the right to determine the value of a currency on a particular topic is obtained when using a foreign public loan when capitalising the budget deficit. The change in the value of the domestic currency does not constitute a violation of the norms of international monetary law, and the states will not be liable for the consequences to creditors of the loan, but the permissibility of such changes is of particular importance in cases of devaluation and revaluation of the domestic currency. Of course, if the motive for the realisation of this right is met with deliberate causing of damage to the creditors of a loan or is basically a discriminatory one, it will result in its narrowing in legal transactions (Dimitrijević, 2017, pp. 41-42). ${ }^{5}$

In certain cases, in order to protect the national or international security it is possible that the state asks the IMF to grant full enjoyment of lex monetae beyond the above-mentioned principles, where IMF within 30 days, must inform the concrete country about the justification of such measure (Articles of Agreement of the IMF, 2016, pp. 1-20). Even when the IMF finds it justifiable to impose such measures, the recognition of such restrictions in a foreign monetary context may be the subject of numerous disputes. Namely, the recognition of restrictions on the use of domestic currency abroad must be based on the principle of lex loci solutionis, lex contractus or art. 7. The Rome Convention on Contractual Obligations, but they do not even have to be recognised in certain monetary jurisdictions despite the fulfilment of these conditions, i.e. the existence of a legal basis for their extraterritorial application. Article VIII (2) of the Agreement on the IMF imposes limited restrictions on such application.

\section{New trends in the development of international and European monetary law}

The mortgage crisis in the US (2008) and its later expansion to the rest of the world in the form of a global financial crisis have largely influenced the changing of traditional postulates, both in national and international monetary law. Until the first consequences of this global crisis, movements in the balance of payments difficulties (observed globally) did

\footnotetext{
${ }^{5}$ For this reason, Articles IV and VIII of the IMF Agreement determine the limitations of this authorization, in the context of the prohibition of the application of the gold standard, the manipulation of a change in value that jeopardizes effective payments or the acquisition of benefits and unfair competitive advantage over other members as well as the involvement in the practice of multiple exchange rates (which is strictly forbidden).
} 
not initiate some serious demands for radical monetary reforms. Despite the widespread viewpoint that after the economic and financial decline, the international monetary system would regain the distorted balance per se, that did not happen in practice and some serious legal reforms have emerged. In the example of EU debt crisis, affected Member States have become especially aware of the significance of the legal concept of economic policy co-ordination for the normative and economic efficiency of monetary solutions. Also, the primary sources of monetary law, due to their rigidity and difficult process of adaptation (in some ways became a relic of traditional economic integration) and therefore had to be supplemented by provisions of secondary legislation embodied in new institutional models of economic governance, such as the European Semester, European Stability Mechanism and the Treaty on Stability, Coordination and Governance in the EMU (Fiscal Stability Treaty) that initiated monetary and fiscal disputes before the European Court of Justice. This is complementary with the new tasks of ECB in implementation of forward guidance and nonstandard monetary policy measures in preventing future market risks (Conti-Brown \& Lastra, 2018, p. 188). The handling of the Court in fiscal disputes (related to the application of fiscal rules) and monetary disputes pointed to the urgent need to educate judges, advocates and lawyers for acquiring specialized knowledge in the field of monetary law. The role of soft law in optimal regulation of monetary relations is crucial, because it balances between extremely dynamic monetary events that require the intervention of public authorities, on the one hand, and insufficiently adaptable primary monetary legal sources whose slow adaptation (reforming) potentially threatens to deepen the external time-lag in fulfilling desired results, on the other hand. This does not mean that secondary legal sources are in conflict with the primary one, since we must not forget that the primary legal projections are conditio sine qua non for determination the monetary order in dimensions of its financial legitimacy, credibility and transparency. The hybrid character of monetary law in certain circumstances can also give major importance to the precedents presented in secondary legislation (for example, no bailout clause for public debt in EU is relativized in practice). Mandatory introduction of a provision on financial support eligibility represents a major change in European monetary law. Success in the application of this provision is conditioned by factors affecting the degree of predictability and stability of the legal result that are expected from its application (Wojcik, 2016, p. 92).

Of course, the mentioned does not speak about the imperfection of monetary norms, but in our opinion, this only confirms the "life" of this branch of law, which does not pretend to be perfect in its nomotechnics, but surely distant from real events in the economic sphere of social life! As monetary law stands in a close synthetic-dialectical connection with monetary finance as an economic discipline, the fact that in some cases secondary legal sources protect the economic stability against the legal and not so surprising. Moreover, the question that here arises is whether the implementation of monetary norms at the moment of international crisis diminishes the distinction between legal and economic security, which are observed trough the same social value instead of the separate (opposing) levels, which once again confirms its sophisticated nature that goes beyond all limitations of others types of legal norms that cannot withstand a "test" of global economic and political earthquakes. 


\section{Conclusion}

In considering the subjects of international and European monetary law, we must take into account the fact that it evolved from national monetary law, which has long been studied almost exclusively in the domain of private (civil) law because monetary obligations are a very widespread element of different types of freight contracts. We consider that this approach in defining the national monetary law is rather unilateral and as such leaves space for numerous legal gaps, which can partly explain the unsatisfactory legal arguments of the courts in resolving monetary disputes with an international context. Namely, we consider that the monetary norm is conceived as a special form of a legal norm that governs social relations with the monetary element in the broadest sense of the word. At the moment of the monetary event determined by concrete monetary norm, the abstract monetary relationship becomes a concrete one and, as such, produces the effects in the monetary circulation. This hybrid factual situation is not solely determined by legal facts, but also by some economic standards, which explain that in the legal definition of money, we must respect the functions of money as an economic category defined in the broadest sense, too. If we carefully look at events in regional and international monetary relations in the last decade, we can notice a new wave of international monetary law, more intense, richer and more complex than ever before in monetary history. New tendencies are characterised by the primacy of soft law over primary monetary solutions, new jurisdictions of international judicial instances for resolving monetary and fiscal disputes, new central bank powers, the evolution of monetary sovereignty concept, and disintegration process of international monetary law which nowadays includes IMF Law and ECB Law as separate positive legal branches. All mentioned is accompanied by serious reforms of the national monetary regulations and financial standards that constitute the global financial architecture, whose pillars are now reinforced in order to maintain monetary and general financial stability as a global public good. Lex monetae in these new occasions is much more than just a principle, it becomes effective axiological tool and common value pattern which invokes new arrangements and institutional reforms of the IMF in order to create an efficient and sustainable legal framework for financial supervision. From the other side, there is also a tendency to consolidate international monetary law at more "human approach" considering the influence of IMF and ECB on the protection of social and economic rights.

\section{References}

Binder, J. H. \& Gorstos, C. V. 2016. A European Banking Union: A Compendium. C. H. Beck, Hart \& Nomos.

Byttebier, K. 2017. Towards a New International Monetary Order. Munich: Springer Economic and Financial Law \& Policy - Shifting Insights \& Values 1.

Conti-Brown, P. \& Lastra, M. R. 2018. Research Handbook on Central Banking. London: Edward Elgar Publishing.

Dimitrijević, M. 2017. Monetary Sovereignty in Contemporary International and Monetary 
Law. In: South Eastern Europe and European Union-Legal Perspective (ed. SEE EU Cluster of Excellence in European and International Law), 3 (1). Saarbrucken: Verlag Alma Mater, pp. 41-53.

Dimitrijević, M. 2018. Institucije međunarodnog monetarnog prava. Niš: Centar za publikacije Pravnog fakultet Univerziteta u Nišu.

Giovanoli, M. (ed). 2000. International Monetary Law: Issues for the New Millennium. Oxford: Oxford University Press.

Gleson, S. 2018. The Legal Concept of Money. Oxford: Oxford University Press.

Gold, J. 1979. Legal and Institutional Aspects of the International Monetary System - Selected Essays, Vol. I. Columbia Press.

Hermann, C. \& Dornacher, C. 2017. International and European Monetary Law - An Introduction. Munich: Springer.

Wojcik, K. P. 2016. Bail-In in the Banking Union. Common Market Law Review, 53, pp. 91-138. Lackhoff, K. 2017. A Single Supervisory Mechanism, European Banking Supervision by the SSM: A Practitioners Guide. C. H. Beck, Hart \& Nomos.

Lastra, M. R. 2015. International Monetary and Financial Law. Oxford: Oxford University Press. Mousmoti, M. 2019. Designing Effective Legislation. London: Edward Elgar.

Proctor, C. 2012. Mann on the Legal Aspects of Money. Oxford: Oxford University Press.

\section{Legal sources}

Articles of the Agreement of the International Monetary Fund, 2016. Publication Service of International Monetary Fund. Washington D. C.

Cases C-9/56 and C-10/56 Meroni v High Authority [1957/1958] ECR 133.

Case C-62/14, Gauweiler and Others v Deutscher Bundestag, ECLI:EU:C:2015:400.

Case Concerning the Payment of Various Serbian Loans Issued in France (France v. Serbia), Judgment of 12 July 1929, PJC Rep Series A Nos 20-21

OMT Case, BVerfG, Urteil des Zweiten Senats vom 21. Juni 2016 - 2 BvR 2728/13 -, Rn. (1-220). Available at: http://www.bverfg.de/e/rs20160621_2bvr272813.html. 
Doc. dr Marko B. Dimitrijević

Pravni fakultet, Univerzitet u Nišu, Srbija

e-mail:markod1985@prafak.ni.ac.rs

\title{
EVOLUTIVNI KONCEPT LEX MONETAE U MEĐUNARODNOM I EVROPSKOM MONETARNOM PRAVU
}

\author{
Sažetak
}

Predmet analize u radu jeste sagledavanje primene i derogacije principa savremenog međunarodnog i evropskog monetarnog prava. U tom kontekstu se u prvom delu rada ukazuje na specifičnost predmeta pravnog regulisanja međunarodnih monetarnih odnosa i sagledavaju normativna obeležja međunarodnog monetarnog sistema. U drugom delu rada ukazuje se osnovne postulate međunarodnog monetarnog prava oličene $\mathrm{u}$ principima tradicionalnog lex monetae i lex contractus (njegovim eksternim efektima) sa posebnim akcentom na primenu ovih principa u globalizovanim finansijskim tokovima. Predmet naročite pažnje jeste identifikovanje novog talasa u razvoju pravne regulative monetarnopravnih odnosa, kao i uloga Međunarodnog monetarnog fonda u tom procesu, što prema mišljenju autora, ima značajne implikacije ne samo na očuvanje tekovina i vrednosti međunarodnog monetarnog poretka, već i održavanje unutrašnje monetarne stabilnosti.

Ključne reči: monetarno pravo, EU, monetarna jurisdikcija, Međunarodni monetarni fond, lex monetae, međunarodni monetarni poredak.

Article history:

Received: 25 April 2019

Accepted: 27 January 2020 